\title{
Se o ciúme é um sinal diagnóstico do amor e da melancolia erótica?*
}

\author{
Jacques Ferrand
}

\begin{abstract}
Alessandro Picolomini, em suas Instituições morais, esforça-se para provar que o verdadeiro Amor deve ser isento de todo ciúme, na medida em que aquele que busca algo com a virtude está livre de qualquer outra companhia nessa busca, esperando que ela sirva de destaque e de brilho ao seu mérito. Apenas a imbecilidade teme o encontro com outro porque ela pensa que sua imperfeição ao ser comparada parecerá desmesurada. Plutarco, ao contrário, diz que o elogio da virtude não produz necessariamente efeitos belos, diferentemente da inquietação de querer se parecer com as pessoas de bem e o desejo de atingir a perfeição. Do mesmo modo, o Amor, se não tem um pouco de ciúme, não é ativo nem eficaz. Foi o que inflamou os Amores de Aquiles por sua escrava Briseis, de Menelau por Helena e de Orestes por Hermione.

(...) Eu diria, como Simonides, que é necessário que todo verdadeiro Amor contenha um pouco de ciúme. Por conseqüên-
\end{abstract}

* Publicado originalmente em Ferrand, Jacques. De la maladie d'amour ou mélancholie érotique. Discours curieux qui enseigne à cognoitre l'essence, les causes, les signes et les remedes de ce mal fantastique. Paris: Denis Moreau, 1623. Capítulo XXV, p. 142-146. Tradução livre de Paulo José Carvalho da Silva. 
cia, Phaulius, que entregava voluntariamente sua mulher a Filipe, rei da Macedônia, não tinha por ela um verdadeiro amor. Assim como o infame Galba, que numa noite, ao oferecer um jantar a Mecenas, o viu espreitando sua mulher e fingiu dormir, para que ele pudesse gozar de seus amores. Quando um servente, crendo que seu mestre dormia realmente, aproximou da mesa para recolher um copo de vinho, o que Galba não queria, ele então disse: Não vê que durmo apenas para Mecenas? Um e outro eram da natureza do bode que, segundo os naturalistas, é o único animal que nunca tem ciúme (ainda que a morte violenta de Gratis, morta por um bode, testemunhe o contrário) não mais do que as mulheres dos Tártaros, Lacedemonios, Cipriotas, Rodenses e Assírios.

Todavia, o ciúme insinua-se na alma sob o título de amizade e, assim que ele a ganha, domina-a e a tiraniza, torna os amantes pálidos, paralisados, magros e, muitas vezes, os precipita no desespero, como Lepidus e um milhão de outros. As mesmas causas que servem de fundamento ao amor, servem posteriormente de fundamento ao ódio capital: a virtude, a saúde, o mérito e a reputação do amado. Se pudéssemos escolher, dentre todos os males, o qual estaríamos isentos, na minha opinião, não há outro que devemos evitar tanto como o ciúme. Nos outros males, a pena dura o mesmo tempo que a sua causa, o ciúme, por sua vez, forma-se indiferentemente daquilo que é, do que não é e do que pode não ser. É uma paixão engenhosa que, freqüentemente, tira de um mal imaginário uma viva e verdadeira dor.

(...) Por que somos tão ambiciosos em nossos males que corremos à sua frente e os adiantamos em pensamento? Nós vemos vários que perderam suas amantes porque desconfiaram de sua castidade, da mesma maneira que os melancólicos hipocondríacos acabam adoecendo de tanto medo de ficar doente. Tanto que nós podemos dizer que o ciúme é um peso que nos faz vacilar na fuga, razão pela qual certo autor dizia que a traição e o ciúme são festejados no mesmo dia. É o que comprovam os exemplos: enquanto Danae estava em liberdade, permaneceu casta. Ao passo que se perdeu assim que seu pai Acrisius a prendeu na torre de bronze. Não há cômodo tão bem fechado, nem gabinete suficientemente secreto, onde o desejoso não possa entrar.

\section{JACQUes FerRand (1575-1623)}

Doutor em direito e em medicina pela faculdade de Toulouse, foi médico do duque Claude de Loraine, além de ter desempenhado a função de cônsul. 